Aleksy Pocztowski

Department of Human Capital Management

Cracow University of Economics

\title{
ADDING VALUE FROM HUMAN RESOURCE DEVELOPMENT IN INTERNATIONAL ASSIGNMENTS
}

\section{Abstract}

The article presents the role of Human Resource Development (HRD) in the process of international assignments by identifying how analyses and interventions taken under HRD add value for expatriates and for multinational enterprises. The study is of a conceptual nature and is based mainly on an analysis of the subject literature, the purpose of which is to identify the essence and features of strategic and international HRD and, on this basis, to prepare a model depiction of HRD impact on the creation of values in the process of international assignments.

Keywords: human resource development, international assignments, expatriates, HRD value proposition.

\section{Introduction}

There is a dilemma in human resource development (HRD), namely, that in the literature its great importance is emphasised in the context of contemporary socio-economic challenges and at the same time there are doubts as to whether it is capable of delivering added value in practice. The issue is particularly key and current in the context of HRD aspiring to possess both a strategic and international dimension. One of the areas in which HRD creates value is tasks performed by expatriates in international assignments. These tasks are related to exercising control over foreign subsidiaries of a multinational enterprise (MNE), know-how transfer, using specialists to develop local managers, and building internal consistency. Therefore, they constitute important tools in enterprise development in 
international markets and are now implemented in traditional long-term forms of expatriation and - increasingly - in non-standard forms.

This article presents the place of HRD in the management process of international assignments by identifying analyses and interventions taken under HRD in order to create added value for expatriates and multinational corporations. The study is of a conceptual nature and is based mainly on an analysis of the subject literature. Its purpose is to identify the essence and features of strategic and international HRD and, on that basis, to prepare a model depiction of HRD impact on the creation of value in the process of international assignments. Wherever appropriate, references to the findings of the empirical research have been included.

\section{HRD in the Contemporary Work Environment}

The term Human Resource Development is traditionally used to determine a wide range of issues related to an academic sub-discipline as well as practical applications of the enrichment of knowledge, improvement of skills and capabilities, and shaping of values and attitudes of people in the work environment. It is a unique framework for activities that support people working to develop their personal and organisational competences. At present, HRD is most often associated with such issues as training, development, careers, talent management, learning, and education.

At this point, it is worth remembering that over the past few dozen years there has been a debate in the literature on the essence of HRD, in which issues of an ontological, epistemological, and axiological nature have been discussed. As a result, many definitions of HRD have been created, describing the issues more narrowly, mainly as training and development in the workplace, and more broadly as learning processes in an organisation and management (Gibb 2008, p. 5). An analysis of over 20 definitions of HRD conducted by Hamlin and Stewart (Hamlin \& Stewart 2011) enables us to identify its four core purposes:

- improving individual or group effectiveness and performance,

- improving organisational effectiveness and performance,

- developing knowledge, skills, and competencies,

- enhancing human potential and personal growth (Wilson 2012, p. 7).

Comparing particular definitions of $\mathrm{HRD}^{1}$ that appear in the literature, different approaches to defining the essence of it can be noted, and on this

${ }^{1}$ HRD definitions are reviewed by, among others, Swanson \& Holton (2001, pp. 4-8) and Wilson (2012, pp. 7-8). 
basis the components included within the scope can be juxtaposed: training and development, career development, personal development, enhancing knowledge, skills and attitudes, behavioural change, individual and organisational learning, individual, group and organisational effectiveness and performance, organisational development, management development, leadership development, coaching, knowledge management, change management, vocational education, and development studies.

The interdisciplinary nature of HRD means that its issues are in the field of interest of psychology, sociology, economics, and management. Evolution in how the essence and scope of HRD is perceived can be also noted - from the narrowly understood training-related operations of employees towards a broader perspective that defines HRD in the context of facilitating individual and organisational learning. Those issues are presently examined in the context of challenges arising from the knowledge economy, knowledge enterprises, knowledge workers, and the learning organisation. HRD faces a dilemma consisting in whether to focus on individual learning, meaning the personal development of employees, improvement in their knowledge and skills, or whether to focus on support for organisational learning consistent with the organisation's strategy (Critten 2008, p. 449). A key challenge for HRD in this context is the translation of learning into the knowledge of the organisation by connecting individual, group, and organisational learning. This is where the basic HRD process from the perspective of management at the level of an enterprise is created, having strategic importance for its development (Pocztowski 2007, p. 274).

At this point, it is important to examine the mutual relationship between HRD and HRM and the two approaches. The first treats HRD as a part of HRM, and the other as a separate and complementary process to HRM (Walton 1999, pp. 143-45). It seems that treating HRD as a part of HRM involves a narrower definition of its domain, while treating HRD in the context of organisational learning and the related broader definition of its domain suggest treating HRD as a discipline separate to HRM, though closely related to it.

Activities undertaken for the development of human resources are given strategic importance, which results from the growing role of human capital, being an integral part of intellectual capital, as a competitiveness factor of enterprises, the economy, and of particular individuals in the labour market. Strategic human resources development (SHRD) is a special variety or model of HRD, comprising a consistent set of vertically and horizontally integrated activities in the field of learning and development that contributes 
to achieving strategic goals (Garavan 2007, p. 25). The distinctive features of SHRD include the long-term development of human resources in an organisation, consideration of HRD in the process of planning and implementing a business strategy, supporting effectiveness (performance), stimulating learning processes and changes at the level of units and at the level of the organisation (Garavan \& Carbery 2012, p. 25). SHRD refers to several theories and concepts of management, including the theory of human capital - SHRD as a tool for investing in human capital, the resource-based theory of the enterprise, SHRD as a way of developing the strategic potential in human resources and situational approach to management, and SHRD as a tool for shaping human capital in a manner that takes into account the form of property, the size of the enterprise, its location, the special character of the industry, technological advancement, and cultural factors.

It is also the logical consequence of Organisational Development (OD), the growing complexity of change management, and the new proposal for HRD in the $21^{\text {st }}$ century - that the individual and the principle of value promotion should be at the centre of processes of change (Grieves 2003, pp. 1-25). We may enumerate three typical frameworks of thinking about the place of HRD in the strategic context: modelling special kinds of process and product associated with strategy; SHRD as a result of the evolution of strategic thinking in the literature; and SHRD as a connection between social and technical systems (Gibb 2008, pp. 308-09).

SHRD refers to the concept of management by values and trust management, promoting such values as trust, cooperation, responsibility, and openness; it contributes to facilitating learning processes, problem solving, and as a result to increasing the effectiveness of particular people, teams, and whole organisations. SHRD development is associated with changing approaches to strategic management and the logic of competition under conditions of dynamic change and uncertainty in the environment. The more frequently strategic management takes the form of using occasion (in place of traditional planning goals) in a given period of time, the greater the need to take HRD into account.

Human resources development, as an area of research and implementation in practice, has achieved an international stage ${ }^{2}$, reflecting the influence of globalisation, growing interest in this field in many countries, the continued expansion of transnational corporations, the popularisation of research results, and the development of educational programmes. International

2 J. P. Wilson identifies six main stages of HRD development: individual, team/group, organisational, community, national, and international (Wilson 2012, p. 14). 
human resources development (IHRD) is a broad field that includes formal education processes, the personal development of employees, training and development within an organisation, and learning processes at the national and international level (Wilson 2012, p. 3). This means that particular domains included within the scope of IHRD often constitute a separate subject of research. It would be difficult to find appropriate theories or to formulate principles sufficiently taking into account the special character of various issues occurring at different stages of analysis. In the literature, we may encounter different definitions of $\mathrm{IHRD}^{3}$, which mostly emphasise the individual, organisational, national, and global dimension of learning processes in the international work environment. Thus, we may conduct research and follow IHRD practices with regard to persons performing work in an area that goes beyond national boundaries. There is an area of research and implementation of IHRD in enterprises operating on international markets. Similar activities may be conducted at the level of educational systems in different countries, or even at the international level, e.g. the European Union.

It is, therefore, not easy to formulate a single definition that would take into consideration all the above aspects of IHRD. One of the proposals is to understand that "international human resource development involves the processes for increasing the cognitive, affective and behavioural capacities of all people, organisations and societies globally" (Wilson 2012, p. 14).

The views summarised above on the essence of HRD allow us to state that its domain is specified as a field of study and practice. However, its boundaries are flexible; they depend on the kind of adopted definition and can range from issues of training through learning processes to HRD strategy design on an international scale.

\section{International Assignments - Objectives, Challenges, and Success Factors}

In a general sense, the term "international assignment" means professional activity on foreign markets performed by employees called expatriates. In the literature, different definitions of an expatriate may be encountered. So, in a broader perspective, this notion is defined as a person who migrates temporarily, most often from rich countries, and stays abroad for business, missionary, educational, research or leisure purposes (Cohen 1977, p. 5). In a narrower perspective, an expatriate is understood as

${ }^{3}$ For the essence of IHRD, see Peterson (1997), Metcalfe \& Rees (2005), Wang \& McLean (2007), Potoker (2010), and Wilson (2012). 
a manager or a specialist employed by an international enterprise outside the country of its origin (Harry 2003, p. 284). These people can be employed both by a head office as well as by subsidiaries (branches, divisions) operating in the markets of the host countries, mostly for business purposes and usually for a period of above one year (Tayeb 2005, p. 182). Another way to define this professional group is to include employees working and temporarily residing in the host country. They may come from either the country of origin of a given enterprise or from a third country (Dowling, Festing \& Engle 2008, p. 4). The next definition describes expatriates in a similar manner. According to it, these are employees sent abroad by the employer temporarily, beyond the borders of their country of origin, to perform certain tasks (Perkins 1997, p. 71). The above-mentioned definitions, despite certain differences, allow us to identify the common features of expatriates. These include being delegated to work for a specified time outside the borders of a given person's country of origin combined with residing abroad at that time (Pocztowski 2012, p. 15). Typical expatriates are employees from the country of origin of an international enterprise. Apart from them, the expatriates group also includes employees from a third country delegated by the head office of an international enterprise to work abroad in the market of the host country. The expatriates group also includes employees delegated from host countries to work at the head office of an international enterprise (Perkins 1997, p. 72). In the literature, they are usually referred to as "inpatriates" (Dowling, Festing \& Engle 2008, p. 97).

On the basis of the criterion of the period of performing work beyond the country of origin, the following typical forms of international assignments can be distinguished:

- business trips - lasting up to one month, often devoted to the present, e.g. the policies of the enterprise,

- short-term assignments, the purpose of which is often to solve current problems,

- extended or contractual assignments - lasting three to twelve months, often related to carrying out projects or solving problems,

- long-term or full assignments - lasting one to five years, characterised by clearly specified roles in the host country that are considered typical of expatriates traditionally understood ${ }^{4}$.

${ }^{4}$ Typologies of international assignments present in the literature on the subject vary among themselves with some details or names. For more on this subject, see Perkins (1997, p. 75), Scullion \& Collings (2006), and Dowling, Festing \& Engle (2008, p. 90). 
Apart from the above mentioned types of international assignments, other non-standard forms of performing work in international markets may be distinguished. These include:

- rotational assignments - short, regular trips abroad in order to perform specific tasks, interwoven with work in the country of origin,

- international commuter assignments - trips to work abroad from the country of origin in a cycle, e.g. every week or every two weeks,

- frequent-flyer assignments - frequent trips abroad without moving permanently,

- virtual assignments - consisting in employees managing or performing other tasks with the use of modern technology, in the form of teleworking, without leaving the country of origin 5 .

These examples highlight the changing designation of the notion of international assignments, from the traditional narrower understanding of a trip abroad lasting from one to five years, with clearly specified objectives and professional roles in the host country, towards understanding such assignments as a method of achieving objectives on foreign markets at different times and in different organisational forms. This is illustrated by the following empirical research findings ${ }^{6}$, which show that enterprises operating on international markets use different forms of trips abroad, among which long-term assignments (1 to 5 years) are very common at $43 \%$, with medium-term assignments (3 to 12 months) at $26 \%$ and short-term assignments (up to 3 months) at $35 \%$. Only international assignments whose period exceeds 5 years are very rare, at just 3\% (Pocztowski 2012, p. 16).

The goals of international assignments and the roles performed by expatriates depend on the international enterprise's strategy and the management philosophy of the Management Board. These may be placed in three main groups, the first of which is filling specified work positions, most often managerial and specialised. Such a practice is to provide the enterprise's head office with a professional service for operations in the markets of the host countries, and often results from a deficit of competent candidates in these markets. The second group of goals includes tasks associated with the development of managerial staff, training and improvement of business unit personnel in the host countries, as well as

${ }^{5}$ For more on this subject, see Dowling, Festing \& Engle (2008), Henderson (2011), Pocztowski (2012), and Purgał-Popiela (2012).

${ }^{6}$ The study was carried out in 2011 in Poland on a group of 100 international enterprises, among which were Polish enterprises operating on international markets and Polish subsidiaries of foreign enterprises (Zarządzanie 2011). 
support for the process of developing corporate values. This can take place both by sending employees from the head office to subsidiaries as well as by sending employees from subsidiaries in the host countries to the head office. The forms of transfer of training content and values may be both design works as well as training. The third group of goals consists of actions involving the development of enterprises on international markets. These include a desire to control foreign operations, the transfer of knowledge, procedures and good practices as well as cultural patterns to units in the markets of the host countries, and making use of opportunities that arise as a result of globalisation (Collings \& Scullion 2007, pp. 219-20; Dowling, Festing \& Engle 2008, p. 89).

Illustration of the above statements stems from the aforementioned empirical studies with regard to the objectives of international assignments. The first is the enterprise's development on a new market ${ }^{7}$, and the second goal of international assignments is transfer of new solutions related to production and management. The next objective focuses on goals including the development of employees in a given subsidiary, the development of employees for future tasks in other subsidiaries, and controlling the subsidiary's operations. Attention is drawn to the relatively low percentage of responses indicating that the goal of an expatriate's mission is to effectively manage the subsidiary due to the lack of suitable candidates in the host country (Pocztowski 2012, p. 19). This seems to be confirmed by the view found in the literature concerning the increasingly easier access to competent, local candidates and the changing roles and importance of expatriates connected with it.

Implementation of the earlier presented goals of international assignments by expatriates creates a number of challenges ${ }^{8}$. The context of implementing the entrusted tasks and playing professional roles is diversified. The host country differs from the country of the expatriate in terms of language, culture, the political system, customs, and standards of behaviour. These differences may affect interpersonal relations, management practices as well as the values and standards professed in the enterprise being part of an international corporation. They also appear in the area of business relations with clients, contractors, and other organisations. Coping with the above challenges requires delivering training, developing the competencies

\footnotetext{
${ }^{7}$ In the literature, the positive relationship between expatriate deployment and subsidiary growth is emphasised (Riaz, Rowe \& Beamish 2014).

${ }^{8}$ The literature suggests that expatriates need support to adjust to the environment in host countries (Mahajan \& Toh 2013).
} 
of expatriates, and stimulating the learning process both for individuals and for the organisation. Human Resource Development as a field of study and practice has an opportunity to make a significant contribution to the success of international assignments. At this point, it seems justified to ask about the nature of this success.

In the traditional narrower perspective, the success of expatriates was identified as the success of an international assignment and achievement of the assumed goals of a trip in the agreed time. The opposite situation, namely, premature return from a mission caused by not coping with assignments and the complexity of the work context, signified a lack of success. The modern broader perspective considers more evaluation criteria, among others, not only the sho rt-term effects of expatriation, i.e. the degree of timely implementation of any commissioned assignments, but also the consequences of expatriation in the long run, for example, for a continued professional career after returning as well as social consequences, including for the family (Purgał-Popiela 2011a, p. 82). In light of current knowledge, the perspective of sustainable human resource management is focused on the creation of value for stakeholders as a point of departure.

It may be concluded that the success of a mission of an expatriate has three dimensions: organisational, individual, and social. The determinants of success in the organisational aspect include the degree of achieving the assumed objectives of the trip, effectiveness measured by the relation of benefit to investment, strengthening the brand of the enterprise in the markets of the host countries, and obtaining or enriching knowledge about expatriation, which may be used in future. In the individual dimension, the success of a participant of an international assignment becomes evident in the area of professional and personal development, and its determinants are the degree of satisfaction from work, gaining or broadening professional skills, promotion, higher salary, strengthening competitiveness in the labour market, and social prestige. The social dimension of success is reflected in the effect of international assignments on family and social life, the development of a contact network, and an increase in the level of human capital in a particular country (Pocztowski 2012, p. 21).

An important issue is identifying factors that determine success during an international assignment. The literature on this problem suggests that this depends on many factors - organisational, environmental, family, and individual - and their significance in particular international assignments is determined by the historical and cultural context (Purgał-Popiela 2011b, 
p. 90). Examples of factors that positively influence success in the work of expatriates are:

- personality traits such as the ability to tolerate ambiguities, flexibility of behaviour, cultural empathy, and interpersonal skills,

- factors related to the motivation of an expatriate such as belief in the mission, compliance of the trip with a professional career, interest in foreign experience, the desire to get to know the culture of the hosting country, and attitudes and behaviours present in it,

- family situation, in particular readiness of a partner to live abroad and their support for an expatriate,

- language skills, among others, ability to learn a language fast and ease in non-verbal communication (Henderson 2011, p. 220).

For comparison, opinions about success factors obtained via empirical research (Zarządzanie 2010) may be mentioned:

"The most important factors of success of an expatriate are strong motivation for the trip, involvement, family situation, and language skills. Frequent causes of failure are frustration due to separation, not fitting in with the team of employees, dissatisfaction with employment conditions"9.

"The success of a foreign mission is mostly affected by individual characteristics such as persistence and goal-orientation, personal and family situation, and the social context of the host country" 10 .

"The success of an assignment is above all affected by individual characteristics such as leadership, intelligence, indomitability, responsibility, orientation towards purpose and success, self-reliance, family situation, and the distance between the countries. The success of expatriation can be threatened by the market, loneliness due to the absence of family (because not all enterprises agree to family trips and do not want to contribute to the costs) as well as lack of knowledge of a language, which is the greatest barrier"11.

Bearing in mind the above opinions, the key success factors for expatriates include:

- high technical skills,

- personality traits and interpersonal skills facilitating work in a socially and culturally diverse environment,

- knowledge about the specific nature of work abroad,

\footnotetext{
${ }^{9}$ Statement of an HR manager of a Polish enterprise sending employees abroad.

${ }^{10}$ Statement of an expatriate working in Poland.

${ }^{11}$ Statement of an expatriate from a Polish enterprise performing international assignments.
} 
- family situation,

- management system of foreign missions in a given organisation.

Below are survey results that reveal the importance of different factors of success of expatriates ${ }^{12}$. They show that professional preparation (average 3.77) and motivation of an expatriate for departure (average 3.72) are indicated most often as success factors. This confirms the popular view that skills and motivation have a key impact on work results. Among the other most frequently indicated factors of success or failure, one should mention: selection of a person lacking the necessary skills (average 3.67), social skills of the employee (3.51), inaccurately defined goals of the assignment (average 3.47), no support from the host subsidiary (average 3.47), and no support from the head office (average 3.41). The listed factors are associated both with the characteristics of expatriates (professional and social skills and motivation) and with processes of trip management (selection of employees, specification of the assignment's goals, and support from the head office and from the subsidiary. Significant factors determining the success of expatriates' international assignments include tolerance and sensitivity to cultural issues (average 3.41), command of the language of the host country (average 3.39), personality traits (average 3.35), monitoring by the head office and maintaining contact with expatriates (average 3.34), agreement on selection requirements with the subsidiary (average 3.34), and remuneration in line with the practice of the subsidiary (average 3.32) (Pocztowski 2012, p. 23).

The literature and empirical research point to rising tendencies in the field of international assignments. These are characterised by a limitation of the traditional form of expatriation, characterised by a long-term stay abroad and occupation of the highest-rank in the organisational hierarchy (Mead \& Andrews 2009, p. 358). In place of this there emerges a different pattern consisting of shorter trips and the use of modern technologies in managing the operations of business units located in host countries. The presented change in the approach to international assignments does not have to lead to changes in the nature of the work of expatriates. It is also worth mentioning the developing new category of self-initiated expatriates. This concerns people who decide themselves to go abroad and work in other countries and thus pursue their professional careers. These changes are reflected in the organisation and methods of expatriate management and also affect the

12 The results show a weighted average of the assessment of the impact of factors on the success of international assignments of expatriates according to the scale: 1 - no impact, 2 - small impact, 3 average impact, 4 - big impact. 
career paths of professionally active employees in international markets. Therefore, they constitute a kind of challenge for theoretical studies and the practical solutions offered within HRD.

\section{The HRD Value Proposition in International Assignments}

Analysing HRD in the international dimension, it should be assumed on the one hand that it remains under the influence of an ever-changing and more complex environment, while on the other hand it focuses on typical problems that appear in organisations functioning under conditions of diversity in international markets. Among these are undoubtedly international assignments and the work of expatriates. Broad knowledge concerning the conditions of performing tasks on international markets allows us to state that HRD may play a key role by developing theoretical frameworks and implementing practical solutions to support processes of individual and organisational learning, and by creating and delivering added value for both expatriates and the international enterprises that send them abroad. The validity of HRD analysis and intervention in international assignments results from the strategic importance of the goals to be met by expatriates and from determining the success factors, which were mentioned in the previous section. If the main factors that determine the success of an expatriate in an international assignment include professional preparation and motivation, and apart from this, interpersonal skills, sensitivity to cultural issues, the support of the enterprise in the process of preparation, stay and return from an international assignment, and the ability to balance work and personal life, then no additional argument is needed to assert that the above factors are the subject of HRD interest as field of study and practice. The creation and provision of added value by HRD in the processes of international assignments can be mentioned in the short- and long-run perspective and in the context of interwoven globalisation and technological changes that constitute a new source of challenges in this field of management but with the possibility of using these new forms to realise objectives in the markets.

When attempting to determine the mechanism by which HRD creates and delivers values in the processes of international assignments (see Fig. 1), the values and their recipients should first be defined. In the present study we will confine ourselves to two groups of recipients, i.e. employees performing international assignments, namely, the individual dimension of value creation, and the organisational dimension, which covers the value 
expected by an enterprise that sends employees to work beyond the borders of their country of origin. Added value for expatriates may be identified by analysing their motives to work on international markets, which include motives connected with professional development (development of skills, careers) and personal development (the desire to get to know the world, new cultures, passion, etc.) as well as social motives (family, social life). On the other hand, added value for an enterprise is determined by the degree of performance of international assignment goals and the roles performed by expatriates. These were discussed earlier, so we will remind you of the most important issues: development of the enterprise in a new market, knowledge transfer, employee development, control of subsidiaries' operations, and improving relations between the head office and the subsidiary.

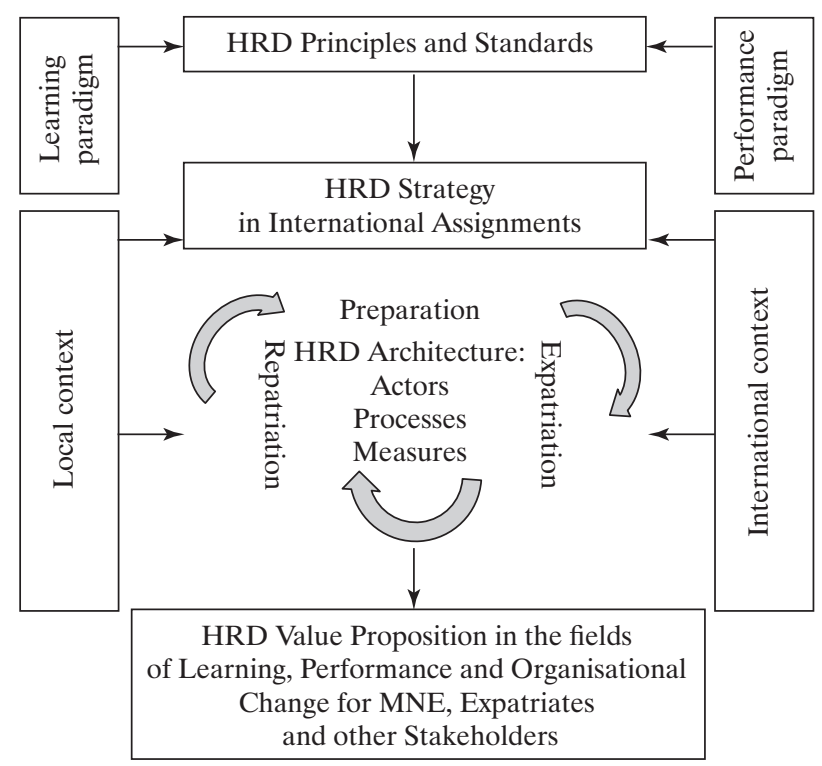

Fig. 1. HRD in International Assignments

Source: own elaboration.

Added value is created and delivered in the management process of international assignments and consists of several stages characterised by a varying degree of detail in the operations assigned to them. Three main sub-processes can be mentioned which form the management of international assignments: 
- preparation of an international assignment,

- expatriation or stay in a host market,

- return from an international assignment (repatriation).

Preparation includes such operations as identifying or updating the descriptions of the roles performed by expatriates during the trip and the skills profiles corresponding to those roles, the recruitment and selection of candidates for the trip, training to prepare for work abroad, specification of salary packages for expatriates, and planning the process of departure in terms of organisation.

The phase of expatriation in the international assignment process includes the trip, the period of adaptation to the new work environment, and performance management in foreign markets. The critical phase in the process of foreign missions is the period of moving from the previous conditions of performing work to the new ones, which are specific to the market of the host country. The phenomenon of cultural shock occurs and as expatriates have various methods of coping with. The key role in implementing the expatriation strategy is played by performance management. Management of the effects of expatriate work includes defining tasks, supporting their implementation, assessing progress in the implementation of the assumed objectives, programmes to improve work performance, and expatriate development. The issue of the effectiveness of the expatriate's activities is of key importance; it requires preparation of a system that is based on the head office's standards and that considers the socio-cultural context of the host country.

Repatriation is the final stage of an international assignment. In this phase, the end of delegation and return to the enterprise are implemented. In the literature, there is wide agreement that completion of an international assignment and return to the country of origin is a challenge both for expatriates and for the enterprise which sends them. This is connected with the possible occurrence of a so-called reverse cultural shock and the risk of the expatriate quitting the enterprise. Research shows that return from an international assignment is not always in line with the expectations of the organisation and the expatriates themselves, the effect of which is that employees quit soon after returning from abroad.

This brief review of the activities undertaken in different phases of the management process of international assignments makes it possible to notice typical areas of HRD analysis and intervention. For instance, the following may be mentioned: training, career development, skills and attitudes development, individual and organisational learning, performance 
management, leadership development, coaching, mentoring, talent management, knowledge management, and change management. The interdisciplinary nature of these areas of HRD justifies dependence on both the learning paradigm and the performance paradigm, which are considered the basic paradigms of HRD theory and practice ${ }^{13}$.

The involvement of HRD to develop values for expatriates and MNE by implementing specified tasks under different phases of the process of managing international assignments takes place most frequently in the form of complementary sequences of activities including observation, planning, action and review, which are defined as an overall HRD process (Gibb 2008, p. 6). The creation and delivery of values for recipients can proceed in various structural systems, created by processes, tools, structures, and the skills of HRD specialists. The shape of this structural solution in an international enterprise depends on such factors as the number of employees, the degree of its internationalisation, the extent to which line managers are included in the recruitment processes, or the use of outsourcing in the field of HRD.

The subject literature and empirical research allow us to state that the modern architecture of HRD in the process of managing the international assignments of employees includes entities from head offices, subsidiaries, and external contractors. There is a growing view that the performance of HR operations undertaken at different stages of expatriate management should include line managers (Gibb 2008, p. 315). At each stage of the international assignment management process, there are strategic tasks for managers and HRD specialists. Thus, in the subject literature the term "strategic partner" is used ${ }^{14}$, as an important role is performed by them in the global work environment, whose main issue is to support learning and changes in multicultural and geographically scattered organisations (Cseh \& Coningham 2012, p. 300). The implementation of tasks by HRD specialists under such conditions requires compliance with standards and ethical norms ${ }^{15}$ when preparing expatriates for tasks in host countries' markets, activities undertaken during performance of the assignment upon return, and after the end of an international assignment.

\footnotetext{
${ }^{13}$ For more on this topic, see Swanson \& Holton (2001, p. 128).

${ }^{14}$ There is an analogy to one of the roles of HR professionals defined as "strategic partner" and covering, among others, change agent, knowledge manager, business expert and consultant. Among a number of other roles assigned to HR professionals are those typical of HRD, e.g. human capital developer, change agent, knowledge facilitator, and coach (Ulrich \& Brockbank 2005, p. 201).

${ }^{15}$ See Standards on Ethics and Integrity, Academy of Human Resources Development (www.ahrd. org).
} 
The approach to performance of the assignment, as well as organisation of the process of preparing expatriates for work on international markets, performing tasks and return after the end of an assignment, is determined by the relations which the head office maintains with the subsidiaries. The shape of those relations derives from professed views on positioning power and the control of risks associated with international management. The evolution of views is visible here, from a traditional belief that power and control over the operations of a subsidiary should be entirely located at the head office of an MNE, through granting subsidiaries the right to some autonomy with regard to how they run their activities, to acknowledgment that in specific situations the subsidiary may affect the practice of management in the head office and other subsidiaries (Tayeb 2005, p. 97).

The nature of these relations may be analysed from the point of view of a head office or a subsidiary. From the point of view of the head office, the degree of freedom of a foreign subsidiary with regard to expatriates' work management, including human resource development, depends in first place on an implemented management strategy, rooted in the values and cultural standards of the MNE. The degree of subsidiaries' compliance with the solutions applied in the markets of host countries significantly affects the expatriation model. We may surmise that the stronger international opinion about the available advantage in the field of technology and managerial knowledge is at the enterprise's head office, the greater the tendency will be to impose its HRD solutions and non-acceptance of local conditions on subsidiaries.

The development of international enterprises, the multi-directionality of their expansion, and their different forms of cooperation and competition have broadened the theory and practice of management, which encourages reflection on antiquated patterns of conduct with regard to relations between the head office and subsidiaries in other countries. More and more managers are becoming aware that subsidiaries have their specific cultural characteristics, that managers and specialists are competent, and that effective human resource management tools have been developed, at least in some host countries' markets. Taking the above into consideration, along with the growing complexity of management on international markets, head offices are willing to adapt solutions with regard to HRD to local conditions.

Referring at this point to the discussion on convergence and divergence in human resource management, it may be concluded that there are more supporters of the cross-vergence approach, which assumes that more and more international enterprises' subsidiaries are simultaneously experiencing 
convergence and divergence, becoming similar in terms of technology and structure while preserving social and cultural autonomy (Mead \& Andrews 2009, p. 416). For the process of international assignment, such an approach means the use of strategy and tools to match the specific nature of a particular assignment, the features of a subsidiary, and the context of the host country. The key role in the practical execution of the idea of cross-vergence is played by relations between the head office and subsidiaries of the MNE.

The creation and delivery of values by HRD is determined by a number of factors, among which special attention should be paid to: the orientation of the management of an enterprise operating on international markets in their approach to human resource development; the relations between the head office and subsidiaries located in international markets; the professionalism of specialists involved in human resource development (HRD professionals); cultural factors; and the organisational-legal form in which international assignment is performed.

\section{Final Remarks}

To sum up, it should be stated that the success of international assignments in the global, culturally and institutionally diverse, variable and uncertain work environment requires activities to be constantly improved, at all stages of this process, in terms of organisation and technologies and in terms of having competent and motivated employees. Meeting this condition means undertaking activities to stimulate the processes of individual and organisational learning, which constitute an area where HRD may create and provide added value both for employees performing international assignments and for the organisation sending them abroad. HRD as a scientific discipline and practice is gaining an interesting development perspective, in which it has the chance to strengthen, not only in rhetoric, but also appreciation in practice. In order for this to happen, HRD must be able to present and improve a value proposition for stakeholders.

\section{Bibliography}

Cohen, E. (1977) "Expatriate Communities". Current Sociology 24(3).

Collings, D. G. and Scullion, H. (2007) "Global Staffing and the Multinational Enterprise" in J. Storey (ed.) Human Resource Management: A Critical Text. London: Thomson Learning. 
Critten, P. (2008) "Creating Corporate Capability: A New Agenda" in M. Muller-Camen, R. Croucher and S. Leigh (eds) Human Resource Management. A Case Study Approach. London: CIPD.

Cseh, M. and Coningham, B. (2012) "Working in Multicultural and Multilingual Environments: HRD Professionals as Learning and Change Gents in the Global Workplace" in J. P. Wilson (ed.) International Human Resource Development. Learning, Education and Training for Individuals and Organisations. Third edition. London: Kogan Page.

Dowling, P. J., Festing, M. and Engle, A. D. (2008) International Human Resource Management. London: Thomson Learning.

Garavan, T. N. (2007) "Strategic Perspective on Human Resource Development". Advances in Developing Human Resources 9(1).

Garavan, T. N. and Carbery, R. (2012) "Strategic Human Resource Development" in J. P. Wilson (ed.) International Human Resource Development. Learning, Education and Training for Individuals and Organisations. Third edition. London: Kogan Page.

Gibb, S. (2008) Human Resource Development. Process, Practices and Perspectives. Second edition. Basingstoke, Hampshire: Palgrave Macmillan.

Grieves, J. (2003) Strategic Human Resource Development. London: Sage Publications.

Hamlin, B. and Stewart, J. (2011) "What Is HRD? A Definitional Review and Synthesis of the HRD Domain”. Journal of European Industrial Training 35(3).

Harry, W. (2003) "Expatriates" in M. H. Tayeb International Management: Theories and Practices. London: Pearson Education.

Henderson, I. (2011) Human Resource Management for MBA Students. London: CIPD.

Mahajan, A. and Toh, M. S. (2013) "Facilitating Expatriate Adjustment: The Role of Advice-seeking from Host Country Nationals". Journal of World Business.

Mead, R. and Andrews, T. G. (2009) International Management: Culture and Beyond. Chichester: John Wiley \& Sons.

Metcalfe, B. D. and Rees, C. J. (2005) "Theorising Advances in Human Resource Development". Human Resource Development International 8(4).

Perkins, J. S. (1997) "Internalisation: The People Dimension - Human Resource Strategy for Global Expansion”. London: Kogan Page.

Peterson, L. (1997) "International HRD: What We Know and What We Don't Know". Human Resource Development Quarterly 8(1).

Pocztowski, A. (2007) "Zarządzanie zasobami ludzkimi. Strategie - procesy - metody" [Human resource management. Strategies - processes - methods]. Second edition. Warsaw: PWE.

Pocztowski, A. (2012) “Znaczenie ekspatriantów w przedsiębiorstwie międzynarodowym” [The role of expatriates in the international enterprise] in A. Pocztowski (ed.) Zarzadzanie misjami zagranicznymi. Indywidualne $i$ organizacyjne aspekty pracy ekspatriantów [Managing international assignments. Individual and organisational aspects of the work of expatriates]. Warsaw: Wolters Kluwer business.

Potoker, E. S. (2010) International Human Resource Development: A Leadership Perspective. Abingdon: Routledge.

Purgał-Popiela, J. (2011a) "Adjustment of Expatriates and Their Spouses as a Challenge for International Human Resource Management". Journal of Intercultural Management 3(1). 
Purgał-Popiela, J. (2011b) "Sukces misji zagranicznej i jego uwarunkowania: spojrzenie z perspektywy organizacji i ekspatrianta" [Success of an international assignment and its determinants from the perspective of an organisation and an expatriate]. Problemy Zarządzania 9(4).

Purgat-Popiela, J. (2012) "Modern Form of Expatriation in Developing Companies on International Markets". Human Resource Management. Warsaw: Institute of Labour and Social Studies 6(89).

Riaz, S., Rowe W. G. and Beamish, P. W. (2014) Expatriate-Deployment Levels and Subsidiary Growth: A Temporal Analysis". Journal of World Business 49(1), January.

Scullion, H. and Collings, D. G. (2006) "Alternative Form of International Assignments" in H. Scullion and D. G. Collings (eds) Global Staffing. London: Routledge.

Swanson, R. A. and Holton, III E. F. (2001) Foundations of Human Resource Development. San Francisco: Berrett-Koehler Publishers Inc.

Tayeb, M. H. (2005) International Human Resource Management: A Multinational Company Perspective. Oxford: Oxford University Press.

Ulrich, D. and Brockbank, W. (2005) The HR Value Proposition. Boston, Massachusetts: Harvard Business School Press.

Walton, J. (1999) Strategic Human Resource Development. London: Prentice Hall.

Wang, X. and McLean, G. N. (2007) "The Dilemma of Defining International Human Resource Development". Human Resource Development Review 7(1).

Wilson, J. P. (2012) “International Human Resource Development” in J. P. Wilson (ed.) International Human Resource Development. Learning, Education and Training for Individuals and Organisations. Third edition. London: Kogan Page.

Zarządzanie (2010) “Zarządzanie grupą 'expatriates' w przedsiębiorstwach działających na rynkach międzynarodowych" [Managing the "expatriates' group in enterprises operating on international markets]. Raport $\mathrm{z}$ badań statutowych Katedry Zarządzania Kapitałem Ludzkim [Research report of the Human Capital Management Department]. Kraków: Cracow University of Economics.

Zarządzanie (2011) "Zarządzanie ekspatriantami z perspektywy interesariuszy przedsiębiorstwa międzynarodowego" [Managing expatriates from the perspective of stakeholders in international enterprises]. Raport z badań statutowych Katedry Zarządzania Kapitałem Ludzkim [Research report of the Human Capital Management Department]. Kraków: Cracow University of Economics.

\section{Abstract}

\section{Rozwój zasobów ludzkich a tworzenie wartości w misjach zagranicznych pracowników}

W artykule przedstawiono miejsce rozwoju zasobów ludzkich (RZL) w procesie zarządzania misjami (wyjazdami) zagranicznymi pracowników. Określono, w jaki sposób analizy i interwencje podejmowane w ramach RZL tworzą wartość dodaną dla ekspatriantów i zatrudniającej ich organizacji. Opracowanie ma charakter koncepcyjny i bazuje na analizie literatury przedmiotu, której celem było określenie istoty i cech strategicznego i międzynarodowego RZL i na tej podstawie opracowanie modelowego 
ujęcia jego wpływu na tworzenie wartości w procesie misji zagranicznych. Konkluzją przeprowadzonych rozważań jest teza, że podejmowanie w ramach RZL działań stymulujących procesy indywidualnego i organizacyjnego uczenia się przyczynia się do tworzenia i dostarczania wartości dodanej w tym procesie.

Słowa kluczowe: rozwój zasobów ludzkich, misje (wyjazdy) zagraniczne pracowników, ekspatrianci (ekspaci), oferta korzyści wynikających z rozwoju zasobów ludzkich. 